\title{
Correction to: The Effect of Health Education Given to Syrian Refugee Women in their Own Language on Awareness of Breast and Cervical Cancer, in Turkey: a Randomized Controlled Trial
}

\author{
Rabiye Erenoğlu ${ }^{1}(\mathbb{D}) \cdot$ Şengül Yaman Sözbir ${ }^{2}$
}

Published online: 30 January 2020

(C) American Association for Cancer Education 2020

\section{Correction to: Journal of Cancer Education} https://doi.org/10.1007/s13187-019-01604-4

The article type for this article should be Original Research Paper.

Publisher's Note Springer Nature remains neutral with regard to jurisdictional claims in published maps and institutional affiliations.

The online version of the original article can be found at https://doi.org/ 10.1007/s13187-019-01604-4

Rabiye Erenoğlu

r_gungor80@hotmail.com; rgungor@mku.edu.tr

Șengül Yaman Sözbir

sengul.yaman@hotmail.com

1 Nursing Department, Gyneacology and Obstetric Nursing Department, Hatay Healthy High School, Mustafa Kemal University, Tayfur Sökmen Campus Alahan, 31060 Antakya, Hatay, Turkey

2 Nursing Department, Gynecology and Obstetric Nursing Department, Faculty of Health Sciences, Gazi University, Ankara, Turkey 